\title{
COMPARISON OF ROAD TRAFFIC DEATH AND INJURY RATES AT PEDESTRIAN CROSSINGS IN EUROPE
}

\section{JULIUS UHLMANN* \\ Chair of Transport System Planning, Bauhaus-Universität Weimar, Weimar, Germany}

Received 3 January 2020; accepted 5 January 2021

\begin{abstract}
For this study, accident statistics of 14 European countries were analysed for the number of fatalities and injuries occurring at pedestrian crossings from 2015 to 2017. The road traffic death rate (killed per 1 million inhabitants) and the road traffic injury rate (injured per 1 million inhabitants) at pedestrian crossings were calculated and compared. It was found that there are large differences between the European countries: The road traffic death rate at pedestrian crossings is the lowest in Great Britain and Germany and the highest in Poland and Lithuania. Statistical analysis showed a significant correlation between road traffic death and injury rates at pedestrian crossings.
\end{abstract}

Keywords: accident statistics, Europe, pedestrian crossings, road accidents, road traffic death rate, traffic safety.

* Corresponding author. E-mail: julius.uhlmann@uni-weimar.de

Julius UHLMANN (ORCID ID 0000-0002-9654-412X)

Copyright (C) 2021 The Author(s). Published by RTU Press

This is an Open Access article distributed under the terms of the Creative Commons Attribution License (http://creativecommons.org/licenses/by/4.0/), which permits unrestricted use,

distribution, and reproduction in any medium, provided the original author and source are credited. 
Contact points of pedestrians and motorised traffic always pose certain risks in terms of traffic safety. There are many different installations, including traffic lights, marked pedestrian crossings, and traffic islands that aim to make the interactions of pedestrians and motorised traffic safer while simultaneously maintaining an adequate level of service for all parties concerned. The pedestrian crossing (PC), colloquially referred to as "zebra marks" is an approach used throughout the world. Although common worldwide, design guidelines for PCs differ between the countries and so does traffic safety. This project deals with evaluation of accident statistics in order to show the differences in traffic safety at PCs in different European countries. The analysis focuses on the number of fatalities and injured persons at pedestrian crossings. Road traffic death and injury rates are also calculated. A multi-country comparison is performed, which highlights the statistical differences in traffic safety at PCs for a variety of countries.

\section{Literature review}

\subsection{General literature on pedestrian crossing safety}

The World Health Organization notes that, "More than one fifth of the people killed on the world's roads each year are not travelling in a car, on a motorcycle or even on a bicycle - they are pedestrians. Pedestrian deaths and injuries are often preventable." (World Health Organization, 2013, p. 3). Pedestrian crossings have been identified as high-risk locations in several publications (Basile et al., 2010, p. 129; World Health Organization, 2013, pp. 32-33). This seems counter-intuitive, as they are intended to be a location where pedestrians are especially safe.

Multiple factors influence the safety and behaviour of pedestrians and motorists when they are at pedestrian crossings. Vehicle velocity is one of the greatest influences on safety (Himanen \& Kulmala, 1988, pp. 195-196; Olszewski et al., 2015; Turner et al., 2006). The design of crossings also has been found to have an influence, especially with regard to the number of lanes (Turner et al., 2006), whether there is a refuge island in the middle of the crossing (Mako \& Szakonyi, 2016; Olszewski et al., 2015; Turner et al., 2006), the lighting conditions (Olszewski et al., 2015) and the presence of warning signs (Turner et al., 2006). The size of the pack of approaching cars (Himanen \& Kulmala, 1988, p. 196) and the ambient light conditions have also proven to be of significance (Uttley \& Fotios, 2017). 
In the last decade, Europe has seen a decline in the number of road traffic accidents resulting in fatalities and injuries (European Commission, 2019, p. 5; International Transport Forum, 2020, p. 11). Estonia has also seen a reduction in traffic rule violations associated with yielding to pedestrians at uncontrolled crossings between 2001 and 2016 (Ess \& Antov, 2017). There are notable differences in traffic safety and its development in the European Union member states (Budzynski et al., 2019). This variety means that an analysis of the differences in traffic safety levels at PCs that includes a number of countries could prove to be especially insightful.

\subsection{Accident numbers at pedestrian crossings}

Several studies that consider PC related accident, fatality, and injury rates for countries throughout Europe already exist, and they will be reviewed in the following section. This review may be incomplete, as not all studies on this subject are available in the languages other than their original, and others might not be indexed properly in the major research databases.

Table 1. Comparison of studies

\begin{tabular}{|c|c|c|c|}
\hline Year & Authors(s) & Country/Region & Findings \\
\hline 2013 & Antov et al. & Tallinn (Estonia) & $\begin{array}{l}22 \% \text { of pedestrian accidents happen at PCs } \\
\text { (Antov et al., 2013, p. } 47 \text { ) }\end{array}$ \\
\hline 2013 & $\begin{array}{l}\text { German Insurers } \\
\text { Accident Research } \\
\text { ("Unfallforschung der } \\
\text { Versicherer") }\end{array}$ & Berlin (Germany) & $\begin{array}{l}\text { 1.7\% of accidents involving pedestrians take } \\
\text { place at a pedestrian crossing. } \\
\text { (Gesamtverband der Deutschen } \\
\text { Versicherungswirtschaft e. V., 2013, p. 10) }\end{array}$ \\
\hline 2013 & $\begin{array}{l}\text { Department for } \\
\text { Transport }\end{array}$ & United Kingdom & $\begin{array}{l}14 \% \text { of pedestrian fatalities and serious } \\
\text { injuries take place at pedestrian crossing } \\
\text { points (Department for Transport, 2015, } \\
\text { p. 6) }\end{array}$ \\
\hline 2015 & $\begin{array}{l}\text { Austrian Motorists' } \\
\text { Association (ÖAMTC) }\end{array}$ & Austria & $\begin{array}{l}\text { The share of pedestrian accidents at PCs in } \\
\text { the total number of pedestrian accidents in } \\
2014 \text { was } 28 \% \text { (Nosé et al., 2015, p. } 7 \text { ) }\end{array}$ \\
\hline 2015 & Olszewski et al. & Poland & $\begin{array}{l}34 \% \text { of pedestrian accidents in Poland } \\
\text { happen at PCs (Olszewski et al., 2015, p. 83) }\end{array}$ \\
\hline 2018 & Budzynski et al. & Poland & $\begin{array}{l}10 \% \text { of all Polish road traffic accident } \\
\text { fatalities take place at PCs (Budzynski et } \\
\text { al., 2019, p. 4) }\end{array}$ \\
\hline
\end{tabular}


While there are several publications that use national statistics to at Pedestrian analyse traffic safety at PCs, only a few publications comparing different countries exist:

EuroTest published a study in 2008 in which ten European countries were compared in regard to pedestrians killed on PCs per 1 million inhabitants. This number was the lowest in the Netherlands (0.6) and Germany (0.8), and the highest in Norway (3.7) and Italy (3.4) (EuroTest, 2008, p. 3).

A 2018 online article by a German vehicle inspection company and traffic safety research organisation DEKRA claims that one in four pedestrian accidents in Europe takes place at a PC (DEKRA Automobil $\mathrm{GmbH}, 2018)$. The methodology used in this study remains unclear.

The previous studies of traffic safety at pedestrian crossings demonstrate marked differences. This points at significant variations in traffic safety and approaches to traffic safety from country to country. However, most of the reviewed studies focus on a single country or region. Therefore, this study has been conducted adopting a uniform analysis methodology and considering a definite analysis period; it will make the issue of traffic safety at PCs more comparable between the countries.

\section{Material and methods}

The main sources used in this study were statistical yearbooks and statistical databases. As not all of the countries in question publish their data, some of the data had to be obtained via direct inquiry at the pertinent institutions. The publicly accessible sources (Lietuvos automobilių kelių direkcija prie Susisiekimo ministerijos, 2018; Ministerstvo vnútra Slovenskej republiky, 2017; Ministerstvo vnútra Slovenskej republiky, 2018; Reditelství služby dopravní policie Policejního prezidia Ceské republiky, 2016; Reditelství služby dopravní policie Policejního prezidia Ceské republiky, 2017; Reditelství služby dopravní policie Policejního prezidia Ceské republiky, 2018; Statistics Finland, (n. d.); Statistisches Bundesamt, 2020) are listed in the references section. The analysis period spanned from 2015 to 2017, with the exception that the data for Italy were only available for 2016 and 2017. As not all countries analysed differentiated between light and severe injuries in their available data, those two categories were combined. It also has to be noted that some of the data sources differentiate between pedestrians and motorists while others do not. In some sources only pedestrian accidents were listed. Therefore, fatalities and injuries of motorists at PCs might be underrepresented. 
Furthermore, the data collection methodology was not always documented for each country, and this means that comparability is ensured only to a certain extent.

The road traffic death rate (RTDR) and road traffic injury rate (RTIR) are both expressed as the number of people killed or injured, respectively, per 1 million inhabitants. These figures were calculated for each country. Neither the Czech Republic nor the Netherlands had data on PC related injuries. A correlation analysis between the road traffic death rate and the road traffic injury rate at pedestrian crossings was conducted. The two main variables were also checked for correlations considering four road safety and socioeconomic factors: overall road traffic death rate, GDP per capita (in Euros), car ownership per 1000 inhabitants, and the relative density of the road network (expressed in $\mathrm{km}$ of road per $\mathrm{km}^{2}$ of area). The data on the total road traffic fatalities, GDP per capita, and car ownership were retrieved from Eurostat (n. d.). The data for the density of the road network came from the OECD (n. d.). The data for these various factors were available for the period from 2015 to 2017. The statistical analysis was conducted using JASP (JASP Team, 2020).

\section{Results}

\subsection{Killed}

The road traffic death rates at PC of various countries show visible differences (Figure 1). While Great Britain, Germany and the Netherlands have very low road traffic death rates, values for both Poland and Lithuania are more than 14 times as high.

When looking at the spatial distribution of the road traffic death rates (compare Figure 2), five distinct regions become visible, and those regions that are spatially closer have comparable road traffic death rates.

1. Western Europe (Germany, the Netherlands, Belgium, and Great Britain) demonstrates the lowest road traffic death rate. Excluding Belgium, Western European countries all have less than 1 death per 1 million inhabitants.

2. Scandinavia (Sweden and Finland) has road traffic death rates similar to Western Europe, and is therefore only geographically distinguished from Western Europe.

3. Central Europe (Czechia, Slovakia, Austria, and Italy) records road traffic death rates that are considerably higher (1.65-2.68) than those of Western Europe and Scandinavia. 


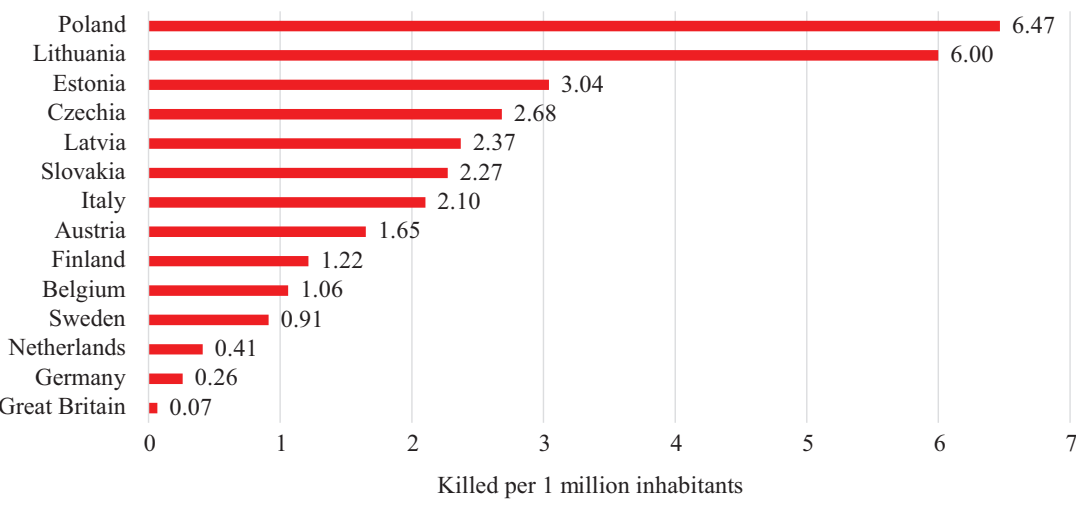

at Pedestrian

Crossings in Europe

Figure 1. Road traffic death rate (number of people killed per 1 million inhabitants) at PCs

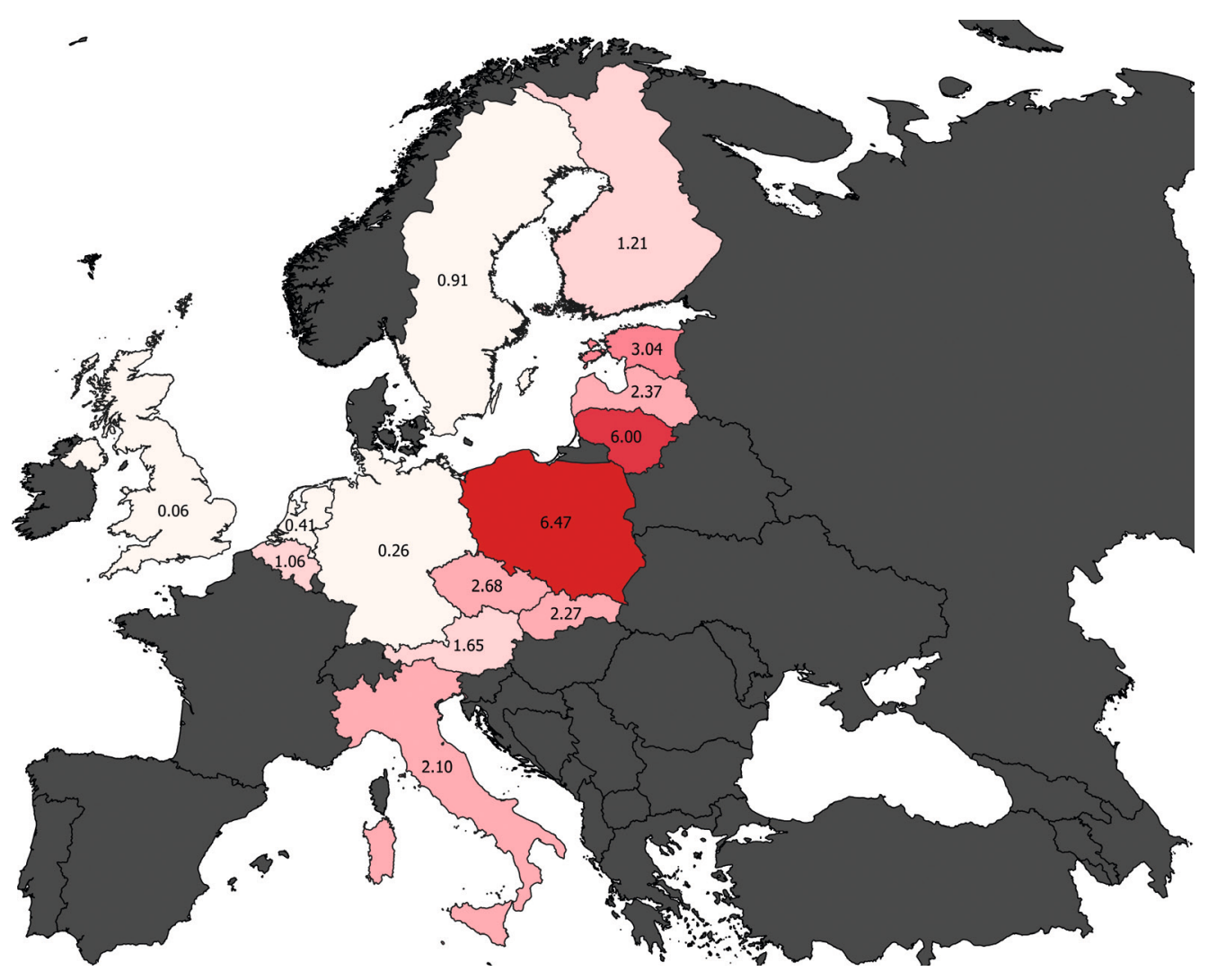

Figure 2. Geographical distribution of road traffic death rates at pedestrian crossings 


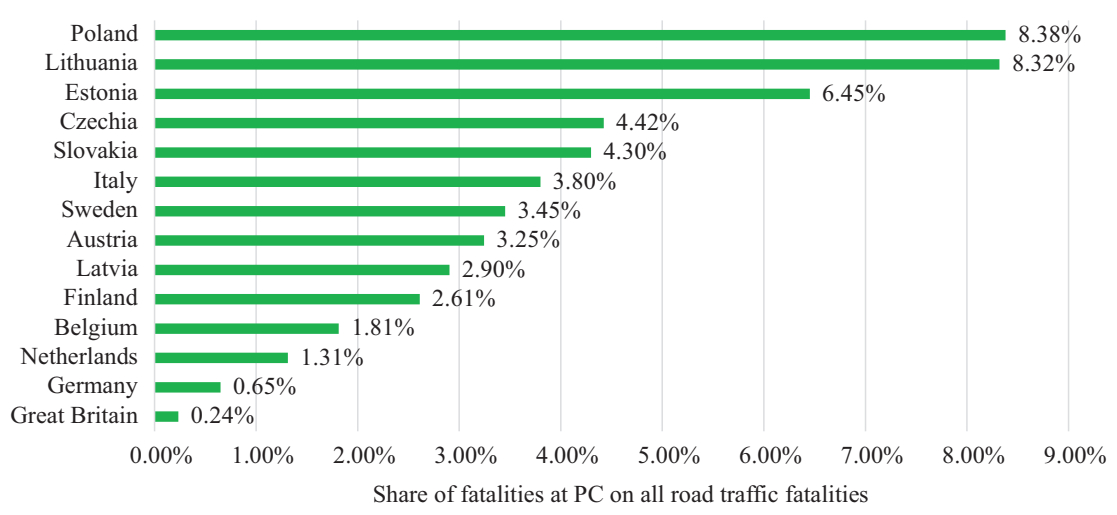

Figure 3. Number of people killed at PCs expressed as a percentage of all road-related fatalities

4. The road traffic death rates of the Northern Baltics (Estonia and Latvia) are similar to those of Central Europe, but the Baltics are geographically separated from Central Europe.

5. Poland and Lithuania have the highest road traffic death rates that clearly distinguish them from any of their geographically adjacent Central European and Northern Baltic neighbours.

In order to analyse the degree at which PC related deaths occur, the share of people killed at PCs was calculated as a percentage of total road-related fatalities for each country (Figure 3). Poland and Lithuania, which have the highest road traffic death rate, also have the highest share of fatalities at PCs. The findings of this study regarding Poland align with those made by Budzynski et al. (2019), whose research found the share to be $10 \%$ in 2018 .

\subsection{Injured}

In contrast to the analysis of the road traffic death rate, where a clear regional pattern may be observed, no systematic spatial deployment was noted for the road traffic injury rate. The grouping from section 3.1 cannot be applied here, as the injury rate differs considerably within the regions. While some countries with a high road traffic death rate have a high road traffic injury rate as well (Lithuania), some countries with a low road traffic death rate have a high road traffic injury rate (Austria, Belgium). Interestingly, Latvia has a very low road traffic injury rate despite a medium-range road traffic death rate. 


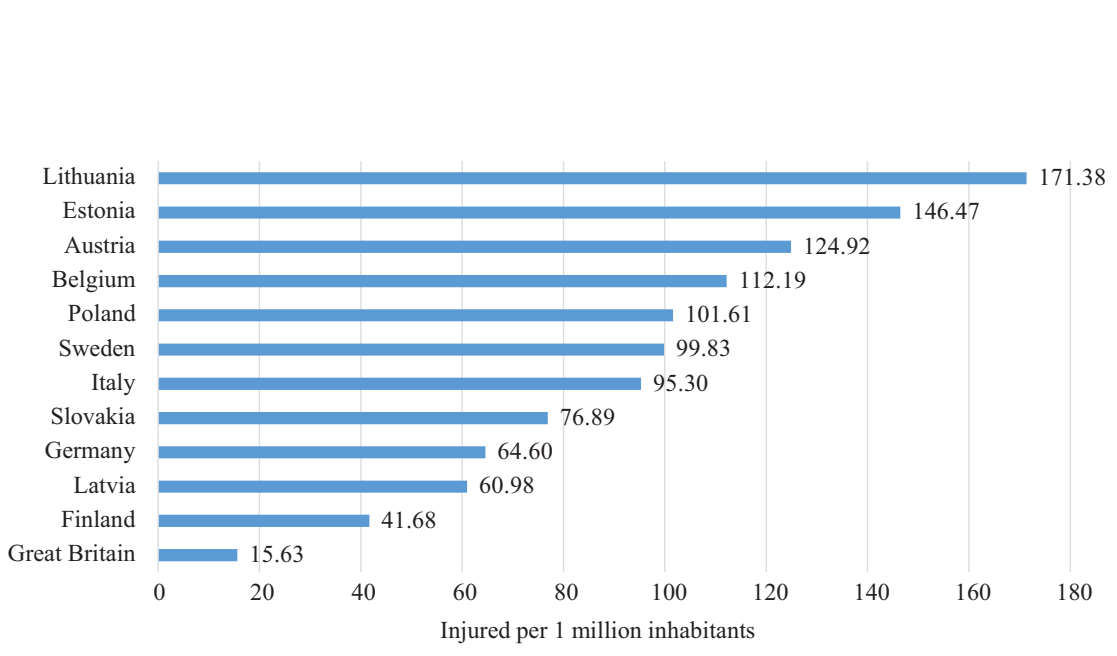

Julius UhImann

Comparison

of Road Traffic Death

and Injury Rates

at Pedestrian

Crossings in Europe

Figure 4. Road traffic injury rate (number of people injured per 1 million inhabitants) at PCs

\subsection{Correlation}

Since the road traffic death rate and road traffic injury rate demonstrate different magnitudes in certain countries (e.g., a relatively high road traffic death rate but a relatively low road injury rate), the question of a possible correlation between the two rates arose. The road traffic death rate and the road traffic injury rate at pedestrian crossings were checked for correlations (Table 2), and a significant correlation was found:

Table 2. Correlation between road traffic death and injury rates at pedestrian crossings

\begin{tabular}{lcc}
\hline & Pearson's $\boldsymbol{r}$ & $\boldsymbol{p}$ \\
\hline RTDR at PC - RTIR at PC & $0.604^{*}$ & 0.038 \\
\hline${ }^{*} p<0.05$. & &
\end{tabular}

The rates at PCs were compared and checked for correlations with the additional consideration of four potentially contributing factors: total road traffic death rate, GDP per capita, car ownership per 1000 inhabitants, and the density of the road network (Tables 3 and 4). The road traffic death rate at PCs correlates with three of the possible contributing factors: total road traffic death rate, GDP per capita, and car ownership per 1000 inhabitants. Interestingly, the road traffic injury rate does not correlate with any of the additional factors. It should also be noted that the total road traffic death rate also correlates with GDP per capita and car ownership (Table 5). 
Table 3. Correlation between road traffic death rate at pedestrian crossings and possible contributing factors

\begin{tabular}{lcc}
\hline & Pearson's $\boldsymbol{r}$ & $\boldsymbol{p}$ \\
\hline RTDR at PC - RDTR total & $0.765^{\star *}$ & 0.001 \\
\hline RTDR at PC - GDP per capita & $-0.785^{\star * *}$ & $<0.001$ \\
\hline RTDR at PC - Cars per 1000 inh. & $-0.559^{*}$ & 0.038 \\
\hline RTDR at PC - Density road network & 0.188 & 0.538 \\
\hline
\end{tabular}

${ }^{*} p<0.05,{ }^{* *} p<0.01,{ }^{* * *} p<0.001$.

Table 4. Correlation between road traffic injury rate at pedestrian crossings and possible contributing factors

\begin{tabular}{lcc}
\hline & Pearson's $\boldsymbol{r}$ & $\boldsymbol{p}$ \\
\hline RTIR at PC - RDTR total & 0.309 & 0.329 \\
\hline RTIR at PC - GDP per capita & -0.323 & 0.307 \\
\hline RTIR at PC - Cars per 1000 inh. & -0.361 & 0.250 \\
\hline RTIR at PC - Density road network & 0.585 & 0.059 \\
\hline
\end{tabular}

Table 5. Correlation between the total road traffic death rate, motorisation, and GDP per capita

\begin{tabular}{lcc}
\hline & Pearson's $\boldsymbol{r}$ & $\boldsymbol{p}$ \\
\hline RDTR total - GDP per capita & $-0.743^{* *}$ & 0.002 \\
\hline RDTR total - Cars per 1000 inh. & $-0.630 *$ & 0.016 \\
\hline${ }^{*} p<0.05,{ }^{* *} p<0.01$. & &
\end{tabular}

\section{Interpretation and discussion}

The results show that fatalities at PCs are a critical issue. This is true especially in Poland and Lithuania, both of which have registered the highest road traffic death rates and the highest and third-highest share of total road-related fatalities. Central Europe and the Northern Baltics also show high road traffic death rates.

A significant correlation between the road traffic death rate at PCs and the overall road traffic death rate shows that traffic safety at PCs is to some extent a reflection of a country's overall level of traffic safety. However, a correlation between the road traffic injury rate at PCs and the total road traffic death rate does not exist. Road traffic death rates at PCs were found to be higher in the countries with a lower GDP per 

contributing factors, therefore, their causality is more likely to be a general phenomenon rather than something specific to PC. A significant correlation between the road traffic death and injury rates at PCs indicates that deaths and injuries at PCs are complex phenomena that need simultaneous analysis and treatment. Furthermore, some countries stand out from the others because they have a high road traffic injury rate despite a low road traffic death rate (such as Austria and Belgium).

A factor that must also be considered when comparing different countries is the difference in the relative number of PCs in each country. Ekman and Hyden (1999) studied the issue of prevalence of PCs in Sweden, a country with a low road traffic death rate but medium road traffic injury rate (a conclusion which can be drawn based on the results of the analysis presented in this paper). They found that $40.3 \%$ of all crossings happened at a zebra crossing and that $40.6 \%$ of the accidents occurred at this type of crossing. This may be seen as an explanation of the values demonstrated by Sweden, as the possibility of crossing the street at a PC in Sweden is rather high simply because of the prevalence of PCs in the country. If one views an accident as a relatively random event, the possibility that an accident will take place while someone is crossing the street at a PC is higher in Sweden simply due to the share of PC crossings in the total number of crossings. Furthermore, road traffic safety rates across Europe and especially in Sweden have improved dramatically in the last 20 years. It is possible that a close match between the share of crossings and the share of accidents found previously by Ekman and Hyden (1999) does no longer persist today. This explanation therefore serves more as a hypothesis that needs further research using the current data and including more countries.

\section{Limitations and implications for future research}

The data presented here can only provide a first impression of traffic safety at PCs throughout Europe. Only a few selected countries were compared, and the time frame was limited to three years. Consequently, longer trends are not reflected in this study. As the absolute number of deaths in some countries is less than ten, small changes between the years and the countries can lead to seemingly large changes in the analysis of death and injury rates. The methods used for data selection in various countries could not continuously be tracked and/or traced, and it is possible some errors exist in the original source materials. To circumvent such issues, it is necessary to obtain all the initial accident 
reports from the police or other first responders and evaluate them regarding the number of accidents occurring at PCs. This, of course, would require an enormous amount of effort both in terms of collection and data evaluation. In order to more accurately compare different countries, the relative share of PCs in the individual countries should be factored into the analysis, including the share of crossing events as calculated by Ekman and Hyden (1999). To minimise the effects of using different methodological approaches, these calculations should be done using a unified method. Conducting such a study would require considerable amount of observation time and effort. Another option could be to calculate the general correction factor based on the number of PCs per inhabitant or even per length of roads. The question remains whether many road administrations can provide the data on the total number of PCs in a country. Other methods of data acquisition could be implemented, such as using image recognition from satellite pictures, a method used previously by Ahmetovic et al. (2017).

In further research on traffic safety at PCs, it is necessary to conduct an analysis that seeks to discern the reasons for different levels of traffic safety in various countries. This research should distinguish between the impact of such factors as design, lighting, and national rules that influence the behaviour of traffic participants. This could be done either by analysing raw accident data for certain parameters or by observing traffic behaviour. A possible approach to such research has been proposed by Basile et al. (2010).

\section{Conclusion}

The analysis of accidents at pedestrian crossings has shown that there are distinct differences between 14 analysed countries. Clear spatial regions can be distinguished with regard to the road traffic death rate at pedestrian crossings, but not for the road traffic injury rate at PCs. Nevertheless, there still is a statistical correlation between both indicators. A correlation also exists between the road traffic death rate at PCs and the total road traffic death rate, but not between the road traffic injury rates in general and at pedestrian crossings in particular.

Further investigation into the reasons for accidents is needed to more comprehensively compare the data from various countries and to develop new strategies for reducing accidents at PCs. Keep in mind that these accidents can in some regions of Europe account for up to $9.15 \%$ of traffic fatalities. Aiming to improve traffic safety for vulnerable road users and make active modes of transportation more attractive, the traffic safety of pedestrians who are crossing the street should be 


\section{Acknowledgements}

The author would like to thank all persons and institutions that provided the data for the study for their support within the project. The work on this article was financially supported by the Bauhaus Research School with funds from the Welt.Raum.Bauhaus programme.

\section{REFERENCES}

Ahmetovic, D., Manduchi, R., Coughlan, J. M., \& Mascetti, S. (2017). Mind Your Crossings: Mining GIS Imagery for Crosswalk Localization. ACM Transactions on Accessible Computing, 9(4). https://doi.org/10.1145/3046790

Antov, D., Rõivas, T., Pashkevich, M., \& Ernits, E. (2013). Safety Assessment of Pedestrian Crossings. In A. Pratelli (Ed.), Transport Systems and Traffic Engineering: v.2. Urban Street Design \& Planning (Vol. 1, pp. 41-53). WIT Press. https://doi.org/10.2495/978-1-84564-847-3/005

Basile, O., Persia, L., \& Usami, D. S. (2010). A Methodology to Assess Pedestrian Crossing Safety. European Transport Research Review, 2(3), 129-137. https://doi.org/10.1007/s12544-010-0036-z

Budzynski, M., Guminska, L., Jamroz, K., Mackun, T., \& Tomczuk, P. (2019). Effects of Road Infrastructure on Pedestrian Safety. IOP Conference Series: Materials Science and Engineering, 603, 42052. https://doi.org/10.1088/1757-899X/603/4/042052

DEKRA Automobil GmbH. (2018). One in Four Pedestrian Accidents in Europe Happens at a Crosswalk. Available from https://www.dekra-roadsafety.com/ en/one-in-four-pedestrian-accidents-in-europe-happens-at-a-crosswalk/

Department for Transport. (2015). Facts on Pedestrian Casualties. Available from https://assets.publishing.service.gov.uk/government/uploads/system/ uploads/attachment_data/file/448036/pedestrian-casualties-2013-data.pdf

Ekman, L., \& Hyden, C. (1999). Pedestrian Safety in Sweden. Available from https://www.fhwa.dot.gov/publications/research/safety/99091/index.cfm

Ess, J., \& Antov, D. (2017). Estonian Traffic Behaviour Monitoring Studies 2001-2016: Overview and Results. The Baltic Journal of Road and Bridge Engineering, 12(3), 167-173. https://doi.org/10.3846/bjrbe.2017.20

European Commission. (2019). Annual Accident Report 2018. Available from https://ec.europa.eu/transport/road_safety/sites/roadsafety/files/pdf/ statistics/dacota/asr2018.pdf 
Eurostat. (n. d.). Persons Killed in Road Accidents by Type of Road: (CARE Data). Retrieved 2019, from https://appsso.eurostat.ec.europa.eu/nui/show. do?query=

Eurostat. (n. d.). Population on 1 January by Age and Sex. Retrieved 2019, from http://appsso.eurostat.ec.europa.eu/nui/show.do?query=

Eurostat. (n. d.). Gross Domestic Product at Market Prices. Retrieved 2020, from https://ec.europa.eu/eurostat/databrowser/view/tec00001/default/ table?lang=en

Eurostat. (n. d.). Passenger Cars per 1000 Inhabitants. Retrieved 2020, from https://ec.europa.eu/eurostat/databrowser/view/road_eqs_carhab/default/ table?lang=en

EuroTest. (2008). Pedestrian crossings survey in Europe.

Gesamtverband der Deutschen Versicherungswirtschaft e. V. (2013). Untersuchungen zur Sicherheit von Zebrastreifen. https://udv.de/de/ publikationen/unfallforschung-kompakt/untersuchungen-zur-sicherheitzebrastreifen

Himanen, V., \& Kulmala, R. (1988). An Application of Logit Models in Analysing the Behaviour of Pedestrians and Car Drivers on Pedestrian Crossings. Accident Analysis \& Prevention, 20(3), 187-197.

https://doi.org/10.1016/0001-4575(88)90003-6

International Transport Forum. (2020). Road Safety: Annual Report 2019. https:// www.itf-oecd.org/sites/default/files/docs/irtad-road-safety-annualreport-2019.pdf

JASP (Version 0.12.2) [Computer software]. (2020). Available from https:// jasp-stats.org/

Lietuvos automobilių kelių direkcija prie Susisiekimo ministerijos. (2018). Statistics of Fatal and Injury Road Accidents in Lithuania: 2014-2017. Vilnius.

Mako, E., \& Szakonyi, P. (2016). Evaluation of Human Behaviour at Pedestrian Crossings. Transportation Research Procedia, 14, 2121-2128. https://doi.org/10.1016/j.trpro.2016.05.227

Ministerstvo vnútra Slovenskej republiky. (2017). Prehl'ad o dopravných nehodách chodcov:: Za obdobie od 01.01. do 31.12.2016 a porovnanie $s$ rovnakým obdobím minulého roka. Územie: Slovensko. Available from http:// www.minv.sk/lnisdn/statistika/20170106_192621.803_2016-12-MS/ statistika/mesacna/chodr/chodr-SR.html

Ministerstvo vnútra Slovenskej republiky. (2018). Prehl'ad o dopravných nehodách chodcov:: Za obdobie od 01.01. do 31.12.2017 a porovnanie s rovnakým obdobím minulého roka. Územie: Slovensko. Available from http:// www.minv.sk/lnisdn/statistika/20190116_194016.728_2017-12-MS/ statistika/mesacna/chodr/chodr-SR.html

Nosé, D., Etl, F., Schönlechner, C., \& Lang, M. (2015). Schutzwegsicherheit ausreichende Beleuchtung als wesent-licher Beitrag zur erhöhten Fußgängersicherheit. Vienna.

OECD. (n. d.). Indicators: Transport Infrastructure: Density of Roads (km per one hundred sq. km). Available from https://stats.oecd.org/Index. aspx?DataSetCode=ITF_INDICATORS\# 
Olszewski, P., Szagała, P., Wolański, M., \& Zielińska, A. (2015). Pedestrian Fatality Risk in Accidents at Unsignalized Zebra Crosswalks in Poland. Accident; Analysis and Prevention, 84, 83-91. https://doi.org/10.1016/j.aap.2015.08.008

Reditelství služby dopravní policie Policejního prezidia Ceské republiky. (2016). PREHLED O NEHODOVOSTI NA POZEMNÍCH KOMUNIKACÍCH V CESKÉ REPUBLICE: za rok 2015. Praha.

Reditelství služby dopravní policie Policejního prezidia Ceské republiky. (2017). PREHLED O NEHODOVOSTI NA POZEMNÍCH KOMUNIKACÍCH V CESKÉ REPUBLICE: za rok 2016. Praha.

Reditelství služby dopravní policie Policejního prezidia Ceské republiky. (2018). ROČENKA NEHODOVOSTI: NA POZEMNÍCH KOMUNIKACÍCH V ČESKÉ REPUBLICE ZA ROK 2017. Praha.

Statistics Finland. (n. d.). Killed and Injured in Road Traffic Accidents by Road User Group, Age and Gender, Type of Accident and Traffic Area in 2012-2019. Available from https://tieliikenneonnettomuudet.stat.fi/PXWeb/pxweb/en/ Tieliikenneonnettomuudet/Tieliikenneonnettomuudet__1_Tienkayttajat/030_ tienk_tau_103.px/?rxid=9271145e-3ec4-4e8f-9785-59a4ffafa7dd

Statistisches Bundesamt. (2020). Verkehrsunfälle: Zeitreihen. Available from https:// www.destatis.de/DE/Themen/Gesellschaft-Umwelt/Verkehrsunfaelle/ Publikationen/Downloads-Verkehrsunfaelle/verkehrsunfaelle-zeitreihenpdf-5462403.pdf?_blob=publicationFile

Turner, S., Fitzpatrick, K., Brewer, M., \& Park, E. (2006). Motorist Yielding to Pedestrians at Unsignalized Intersections: Findings from a National Study on Improving Pedestrian Safety. Transportation Research Record: Journal of the Transportation Research Board, 1982, 1-12. https://doi.org/10.3141/1982-03

Uttley, J., \& Fotios, S. (2017). The Effect of Ambient Light Condition on Road Traffic Collisions Involving Pedestrians on Pedestrian Crossings. Accident; Analysis and Prevention, 108, 189-200. https://doi.org/10.1016/j.aap.2017.09.005

World Health Organization. (2013). Pedestrian Safety: A Road Safety Manual for Decision-Makers and Practitioners. World Health Organization. 